Factors associated with work ability and perception of fatigue among nursing personnel from Amazonia

\section{Fatores associados à capacidade para o trabalho e percepção de fadiga em trabalhadores de enfermagem da Amazônia Ocidental}

\section{Suleima Pedroza Vasconcelos' \\ Frida Marina Fischer"I \\ Alberto Olavo Advincula Reis"II \\ Cláudia Roberta de Castro Moreno" \\ ' Universidade Federal do Acre, Department of Health and Sports Sciences. \\ " Universidade de São Paulo, School of Public Health, Department of \\ Environmental Health. \\ "I Universidade de São Paulo, School of Public Health, Department of Maternal and Child Health.}

The present study was based on the Master's Degree thesis entitled "Avaliação da capacidade para o trabalho e fadiga entre trabalhadores de enfermagem em um hospital de urgência e emergência na Amazônia Ocidental" ("Work ability and fatigue assessment among nursing workers of an emergency and urgent care hospital in the Western Amazon region") presented to the Inter-Institutional Postgraduate Program of the School of Public Health at the Universidade de São Paulo (USP) and Universidade Federal do Acre (UFAC).

Conflito de interesses: inexistente.

Financiamento: nenhum

Correspondência: Suleima Pedroza Vasconcelos. Rua Quintino Bocaiúva, 1927 - Bosque - Rio

Branco - AC CEP: 69909-400. E-mail: suleimav@usp.br

\section{Abstract}

Objective: To analyze factors associated with inadequate work ability and perceived fatigue among nursing professionals. Methods: A cross-sectional study was conducted involving 272 nursing personnel at an emergency hospital in Rio Branco/ State of Acre, Brazil. Data collection was performed using the following instruments: questionnaire on sociodemographic data, working conditions and life styles; the Work Ability Index - WAI, and a questionnaire on perceived fatigue. Bivariate and multiple Poisson regression was used in the analysis of factors associated with work ability and perceived fatigue. Results: The prevalence of inadequate work ability was $40.8 \%$ and presented the following associated factors: female sex ( $\mathrm{RP}=1.84 ; 95 \%$ CI $1.06-3.18$ ); refering: other job commitment $(\mathrm{RP}=1.71$; 1.25 - 2.35); understaffing ( $\mathrm{RP}=1.96 ; 1.10$ - 3.47); repetitive and monotonous tasks $(\mathrm{RP}=1.84 ; 1.24-2.72)$; reporting three or more clinically undiagnosed morbidities $(\mathrm{RP}=1.48 ; 1.06-2.06)$; excessive reported fatigue $(R P=2.37 ; 1.81-3.12)$. The prevalence of severe fatigue was $25.7 \%$ and the associated factors were: repetitive and monotonous tasks ( $\mathrm{RP}=1.74 ; 1.00-3.03$ ); reporting three to five clinically-diagnosed morbidities $(\mathrm{RP}=1.98 ; 1.00-3.11)$ and six or more self-reported morbidities $(\mathrm{RP}=$ 3.79; $2.04-7.03)$. Conclusions: The study revealed that most of the studied population showed reduced work ability and high levels of fatigue. These results point toward the need for interventions on an individual level (such as life conditions) and workplace improvements, looking jointly at the organizational aspects and work environment, particularly organizational aspects.

Keywords: Work ability. Fatigue. Occupational Health. Working conditions. Nursing personnel. Hospital. 


\section{Resumo}

Objetivo: Analisar os fatores associados à capacidade inadequada para o trabalho e à percepção de fadiga entre os profissionais de enfermagem. Método: Estudo transversal desenvolvido com 272 trabalhadores em um hospital de urgência e emergência de Rio Branco/Acre. A coleta de dados ocorreu por meio dos seguintes instrumentos: questionário sobre dados sociodemográficos, condições de trabalho e estilo de vida; Índice de Capacidade para o Trabalho - ICT; e Questionário de Percepção de Fadiga. Para análise dos fatores associados à capacidade inadequada para o trabalho e à percepção de fadiga elevada foi utilizada a regressão de Poisson bivariada e múltipla. Resultados: A prevalência de capacidade inadequada para o trabalho foi de $40,8 \%$, tendo como fatores associados: sexo feminino (RP = 1,84; IC95\% 1,06 - 3,18); referir outro vínculo empregatício ( $\mathrm{RP}=1,71 ; 1,25-2,35)$; número de funcionários insuficiente $(\mathrm{RP}=1,96 ; 1,10$ $3,47)$; tarefas repetitivas e monótonas $(\mathrm{RP}=$ $1,84 ; 1,24-2,72)$; três ou mais morbidades sem diagnóstico médico $(\mathrm{RP}=1,48 ; 1,06$ $2,06)$; fadiga elevada $(\mathrm{RP}=2,37 ; 1,81-3,12)$. A prevalência de fadiga elevada foi de 25,7\% e os fatores associados foram: tarefas repetitivas e monótonas $(\mathrm{RP}=1,74 ; 1,00-3,03)$; referir de três a cinco morbidades com diagnóstico médico $(\mathrm{RP}=1,98 ; 1,00-3,11)$ e seis ou mais morbidades $(\mathrm{RP}=3,79 ; 2,04$ -7,03), segundo a auto-avaliação do profissional. Conclusões: $O$ estudo evidencia que grande parte população estudada apresenta capacidade inadequada para o trabalho e níveis elevados de fadiga, apontando para a necessidade de intervenções no plano individual (condições de vida) e no ambiente de trabalho, principalmente no que tange aos aspectos organizacionais.

Palavras-chave: Capacidade para o trabalho. Fadiga. Saúde do trabalhador. Condições de trabalho. Enfermagem. Hospital.

\section{Introduction}

Due to its nature and characteristics, nursing work frequently involves dealing with situations of pain and suffering experienced by patients and it could be a source of suffering for nursing professionals themselves. This context could be aggravated by the form of work organization, as a result of the exercise of power performed by the several participants involved in health organizations $^{1}$. In the hospital environment, activities are frequently characterized by fragmented division of tasks, rigid hierarchical structure to meet routine requirements and understaffing in quantitative and qualitative terms, causing high absenteeism and sick leave indices ${ }^{2}$. These factors could trigger symptoms characteristic of burnout, in addition to work dissatisfaction $^{3,4}$. Poor working conditions may lead to presenteeism ${ }^{5}$ and workers seeking other jobs $^{6}$. In addition, the strain caused by work requirements may lead to chronic and acute physiological responses, psychological reactions and behavioral changes, and a possible decrease in functional capacity and work ability ${ }^{7}$.

Work ability is a dynamic process that changes throughout life and it results from the interaction between human resources and work characteristics ${ }^{8}$. This ability can be maintained or even restored if workers' health promotion and prevention measures are conducted.

Apart from the reduction in work ability, strain can also have an immediate effect, namely fatigue. This could be the result of occupational activities that require intense physical and mental activity associated with organizational stressors. Prolonged working hours, night jobs and double shifts stand out among these stressors ${ }^{9}$.

According to Lewis and Wessely ${ }^{10}$, the prevalence of fatigue in workers of several sectors could vary between 7 and $45 \%$, depending on the instruments used to measure it. By analyzing workers of a printing press in the city of São Paulo, Queiroz ${ }^{11}$ observed a prevalence of fatigue of $37.5 \%$. 
In this context and especially with regard to organizational aspects, nursing work exposes workers to several physical and mental stressors, which may interfere with their work ability and cause fatigue. Thus, the present study aimed to analyze the factors associated with inadequate work ability and high perception of fatigue.

\section{Methods}

A cross-sectional study was conducted with nursing professionals (nurses, nursing technicians and assistants), who worked in an emergency and urgent care hospital situated in the state of Acre, in Northern Brazil. The team was comprised of 312 workers. The inclusion criteria were as follows: to perform direct health care activities, to have worked in the study hospital for at least six months, and to be actively performing one's functions. A total of $4.5 \%$ of workers did not meet these criteria, so that 298 remained. Of these, $8.7 \%$ refused to participate in the study. Thus, the study population was comprised of 272 workers.

Data were collected with questionnaires used to obtain information about socio-demographic data, working conditions, lifestyle and leisure, work ability and perception of fatigue, between October 2008 and March 2009. A pilot study was conducted, aiming to test the instruments and train research field assistants.

Inadequate work ability and high perception of fatigue were considered as the dependent variables. The first variable was measured by calculating the Work Ability Index $-\mathrm{WAI}^{12}$, using the version validated in Brazil $^{13}$. The WAI score varied from 7 to 49 points. Among individuals aged between 18 and 34 years, the WAI was considered to be inadequate when the score was lower than 40 points and adequate when it was equal to 40 or higher. Participants aged 35 years or more and with a WAI lower than 37 points were considered to have an inadequate work ability, while those who obtained scores equal to or higher than 37 had an adequate work ability ${ }^{14}$.
The "high perception of fatigue" dependent variable was assessed with the Portuguese version of the Questionnaire about Perception of Fatigue ${ }^{15}$ adapted by Metzner and Fischer ${ }^{16}$. The score of this scale varied between 30 and 150 points, being dichotomized into low perception of fatigue (values from 30 to 62 points) and high perception of fatigue (values equal to 62 points and higher).

Workers' socio-demographic aspects, working conditions (physical environment, work organization and processes), leisure and living conditions, and reported morbidities with and without diagnosis were considered to be independent variables.

This research project was sent to the Universidade de São Paulo School of Public Health and Universidade Federal do Acre Research Ethics Committees and it was duly approved by both. All participants signed an Informed Consent Form.

\section{Statistical analyses}

Losses were analyzed by comparing the population that participated in this study with those that did not, according to sex, age, work sector and length of time working in the hospital and using Pearson's chi-square test. There were no statistically significant differences among groups in this analysis. Analyses of absolute and relative frequencies of categorical variables and descriptive statistics of continuous variables (with position and dispersion measurements) as socio-demographic data, working conditions and lifestyle and reported morbidities were performed to characterize the population.

All independent variables were initially tested using Pearson's chi-square test to analyze factors associated with inadequate work ability and high perception of fatigue.

Only the variables with $p<0.20$ were included in the bivariate and multiple Poisson model with robust variance. Poisson regression was used due to the high prevalence of inadequate work ability and high perception of fatigue ${ }^{17}$. 
Multiple analysis was performed with the hierarchical analysis technique proposed by Victora ${ }^{18}$. The factors analyzed were gathered into groups, ordered according to the influence they have on work ability and perception of fatigue in workers. In this sense, socio-demographic factors were considered as distal determinants, which had a direct influence on the following remaining groups: working conditions and lifestyle and reported clinically diagnosed and undiagnosed morbidities. It should be emphasized that sex and age remained in the model, regardless of the level of association, as they were considered control variables.

The variables that remained in the model were those that reached a p-value < 0.05 . A $5 \%$ significance level was considered in all analyses.

The software program used in all analyses was the Stata 10 (Stata Corporation, College Station, TX, USA).

\section{Results}

The majority of workers were women (82\%); with a mean age of 41.7 years (sd=9.3), varying between 23 and 65 years; and married (51.4\%). The mean level of education was 14.7 years $(\mathrm{sd}=1.9)$. With regard to the professional category, the majority of them were nursing technicians (50.3\%). Professionals had a mean weekly workload of 63.7 hours ( $\mathrm{sd}=13.3$ ), varying between 30 and 108 hours. It should be emphasized that $42.3 \%$ of these professionals worked more than 60 hours per week.

With regard to the workload in the study hospital, $46.3 \%$ of the nursing team performed both day (from 7.00am to 1.00pm and from $1.00 \mathrm{pm}$ to $7.00 \mathrm{pm}$ ) and night shifts (from 7.00pm to 7.00am).

The WAI of the population studied ranged from 25 to 49 points, with a mean of 38.1 points ( $\mathrm{sd}=5.7$ ). After the categorization, $40.8 \%$ of participants had an inadequate work ability.

In the first stage of analysis of factors associated with inadequate work ability with
Pearson's chi-square test, the following variables showed a $\mathrm{p}$-value $<0.20$ : $\operatorname{sex}(\mathrm{p}=0.004)$; marital status ( $\mathrm{p}=0.108$ ); having other jobs (0.141); and hospital sector $(\mathrm{p}=0.166)$; cleaning ( $\mathrm{p}=0.008)$; lighting $(\mathrm{p}=0.010)$; temperature $(\mathrm{p}=0.012)$; ventilation $(\mathrm{p}=0.071)$; organized environment $(\mathrm{p}=0.023)$; furniture $(\mathrm{p}=0.089)$; pace of work $(\mathrm{p}=0.018)$; number of professionals $(\mathrm{p}=0.010)$; repetitive and monotonous tasks $(\mathrm{p}=0.045)$; cooperation among team workmates $(\mathrm{p}=0.050)$; stifling environment ( $\mathrm{p}=0.005)$; physical activity ( $\mathrm{p}=0.192$ ); reported clinically undiagnosed morbidities $(\mathrm{p}=0.004)$; and perception of fatigue $(\mathrm{p}<0.001)$.

After this stage, bivariate and multiple Poisson regression was performed, following the hierarchical model. The data in Table 1 show the variables that had a statistically significant association with inadequate work ability.

The independent variables that were initially tested with Pearson's chi-square test and obtained a p-value $<0.20$ were as follows: $\operatorname{sex}(\mathrm{p}=0.096)$; age $(\mathrm{p}=0.064)$; income ( $\mathrm{p}=0.090$ ); beginning of one's work life ( $\mathrm{p}=0.165)$; hospital sector $(\mathrm{p}=0.032)$; temperature $(\mathrm{p}=0.125)$; ventilation $(\mathrm{p}=0.144)$; stifling environment $(\mathrm{p}=0.085)$; equipment $(\mathrm{p}=0.109)$; pace of work $(\mathrm{p}=0.094)$; number of professionals $(\mathrm{p}=0.089)$; repetitive and monotonous tasks $(\mathrm{p}=0.019)$; cooperation among team workmates $(\mathrm{p}=0.151)$; and reported clinically diagnosed morbidities $(\mathrm{p}<0.001)$.

In the subsequent stage, bivariate and multiple Poisson regression was performed. The variables that had a statistically significant association with high perception of fatigue were as follows: "repetitive and monotonous tasks" and "reported clinically diagnosed morbidities”, as shown in Table 2.

\section{Discussion}

The majority of nursing professionals $(91.3 \%)$ who worked in the study hospital participated in the present study. According to Fowler Jr. ${ }^{19}$, values higher than $75 \%$ are considered to be adequate. Thus, the results 
Table 1 - Estimate using the Raw (bivariate) and multiple (adjusted) Poisson regression model for inadequate work ability in nursing professionals of the Casualty and Emergency Hospital of Rio Branco, 2008-2009

Tabela 1 - Estimativa do modelo de regressão de Poisson bruto (bivariado) e múltiplo (ajustado) para capacidade inadequada para o trabalho entre profissionais de enfermagem do Hospital de Urgência e Emergência de Rio Branco, 2008-2009

\begin{tabular}{llllllll}
\hline Variables & \multicolumn{3}{c}{ Inadequate WAI } & & \multicolumn{2}{c}{ Crude PR } & \multicolumn{2}{c}{ Adjusted PR } \\
\cline { 2 - 7 } & N & F & $\%$ & RP & IC & RP & IC \\
\hline
\end{tabular}

Socio-demographic

Sex\#

$\begin{array}{lccccccc}\text { Male } & 49 & 11 & 22.4 & 1 & & 1 & \\ \quad \text { Female } & 223 & 100 & 44.8 & 1.99 & 1.16 ; 3.43 & 1.84 & \mathbf{1 . 0 6 ; 3 . 1 8} \\ \text { ge\# } & & & & & & & \\ \quad \text { Between 18 and 39 years } & 111 & 42 & 37.8 & 1 & & 1 & \\ \text { 40 years and more } & 161 & 69 & 42.7 & 1.13 & 0.84 ; 0.52 & 1.00 & 0.74 ; 1.36\end{array}$

\section{Work-related*}

Having other jobs

$\begin{array}{lccccccc}\text { No } & 213 & 82 & 39.5 & 1 & & \mathbf{1} & \\ \text { Yes } & 59 & 29 & 49.2 & 1.28 & 0.93 ; 1.74 & \mathbf{1 . 7 1} & \mathbf{1 . 2 5 ; 2 . 3 5}\end{array}$

\section{Stifling environment}

Never

Rarely

Sometimes

Always/frequently

$65 \quad 22 \quad 33$

Number of professionals

Always/frequently

Sometimes

$14 \quad 02$

33.8

14.3

1

$44 \quad 13$

29.5

0.42

$0.11 ; 1.59$

1

148

74

50.0

0.87

$0.49 ; 1.54$

0.28

$0.09 ; 0.82$

1.48

$1.01 ; 2.15$

0.14

$0.34 ; 1.16$

0.90

$0.57 ; 1.42$

Rarely

$80 \quad 26$

32.5

30.6

1

60.0

0.94

$0.58 ; 1.54$

1

$20 \quad 12$

1.85

$1.14 ; 2.98$

0.84

$0.61 ; 1.55$

Never

109

54

49.5

1.52

$1.05 ; 2.20$

1.96

$1.10 ; 3.47$

1.22

$0.82 ; 1.81$

\section{Repetitive and monotonous tasks}

Never

Rarely

Sometimes

$79 \quad 26$

26

32.9

1

26.7

0.81

$0.33 ; 1.99$

1

$\begin{array}{ll}15 & 23\end{array}$

37.1

1.13

$0.72 ; 1.77$

1.98

$0.68 ; 5.72$

Always/frequently

115

50.4

1.53

$1.06 ; 2.21$

1.61

$1.01 ; 2.56$

Reported clinically undiagnosed morbidities**

No diseases

$\begin{array}{lccccccc}\text { No diseases } & 127 & 40 & 31.5 & 1 & & 1 & \\ \text { Up to two diseases } & 91 & 40 & 44.0 & 1.39 & 0.99 ; 1.97 & 1.28 & 0.92 ; 1.78 \\ \text { Three or more diseases } & 54 & 31 & 57.4 & 1.82 & 1.29 ; 2.57 & 1.48 & \mathbf{1 . 0 6 ; 2 . 0 6} \\ \text { rception of fatigue*** } & & & & & & & \\ \text { Low } & 202 & 59 & 29.2 & 1 & & 1 & \\ \text { High } & 70 & 52 & 74.3 & 2.54 & 1.97 ; 3.28 & 2.37 & \mathbf{1 . 8 1 ; 3 . 1 2}\end{array}$

Up to two diseases

Three or more diseases

Perception of fatigue ${ }^{* * *}$

\# Control variables. * Adjusted for sociodemographic variables. ${ }^{* *}$ Adjusted for sociodemographic variables and for work-related variables. ${ }^{* * *}$ Adjusted for sociodemographic variables, work-related variables, and for reported clinically undiagnosed morbidities

\# Variáveis de controle. * Ajustados pelas variáveis sociodemográficas. ** Ajustados pelas variáveis sociodemográficas e pelas variáveis relacionadas ao trabalho.

*** Ajustados pelas variáveis sociodemográficas, pelas variáveis relacionadas ao trabalho e morbidades referidas sem diagnóstico médico 
Table 2 - Estimate using the Raw (bivariate) and multiple (adjusted) Poisson regression model for perceived severe fatigue in nursing professionals of the Casualty and Emergency Hospital of Rio Branco. 2008-2009

Tabela 2 - Estimativa do modelo de regressão de Poisson bruto (bivariado) e múltiplo (ajustado) para percepção de fadiga elevada entre profissionais de enfermagem do Hospital de Urgência e Emergência de Rio Branco. 2008-2009

\begin{tabular}{lllllllll}
\hline & \multicolumn{3}{c}{ High perception of fatigue } & & \multicolumn{2}{c}{ Crude PR } & \multicolumn{2}{c}{ Adjusted PR } \\
\cline { 2 - 8 } Variables & N & F & $\%$ & RP & IC & RP & IC \\
\hline
\end{tabular}

\section{Socio-demographic}

Sex\#

\begin{tabular}{lccccccc} 
Male & 49 & 08 & 16.3 & 1 & \multicolumn{3}{c}{1} \\
Female & 223 & 62 & 27.8 & 1.70 & $0.87 ; 3.32$ & 1.62 & $0.85 ; 3.09$
\end{tabular}

Age\#

Between 18 and 39 years

$\begin{array}{lll}111 & 22 & 19.8\end{array}$

40 years and more

223

48

29.8

1.50

$0.96 ; 2.34$

1.48

$0.95 ; 2.39$

Work-related variables*

Repetitive and monotonous tasks

$\begin{array}{lccccccc}\text { Never } & 79 & 12 & 15.2 & 1 & & 1 & \\ \text { Rarely } & 15 & 02 & 13.3 & 0.88 & 0.22 ; 3.54 & 0.74 & 0.21 ; 2.58 \\ \text { Sometimes } & 62 & 17 & 27.4 & 1.80 & 0.93 ; 3.49 & 1.71 & 0.87 ; 3.36 \\ \text { Always/frequently } & 115 & 39 & 33.9 & 2.23 & 1.24 ; 3.99 & \mathbf{1 . 7 4} & \mathbf{1 . 0 0 ; 3 . 0 3}\end{array}$

Reported clinically diagnosed morbidities**

Between one and two

morbidities

126

17

13.5

1

1

Between three and five

morbidities

108

30

27.8

2.06

$1.20 ; 3.52$

1.98

$1.00 ; 3.11$

Six or more morbidities

38

23

60.5

4.49

$2.69 ; 7.49$

3.79

$2.04 ; 7.03$

\# Control variables. * Adjusted for sociodemographic variables. ** Adjusted for sociodemographic variables and for work-related variables \# Variáveis de controle. *Ajustados pelas variáveis sociodemográficas. ** Ajustados pelas variáveis sociodemográficas e pelas variáveis relacionadas ao trabalho

found in this investigation are representative. Another important factor refers to the similarity between study participants and non-participants.

The results of this study showed a high prevalence of inadequate work ability $(40.8 \%)$. These data corroborate studies with nursing professionals conducted in Brazil and in other countries that also found high indices of work inability ${ }^{20,21,22}$. Work inability among nursing professionals could also be attributed to the work characteristics themselves, which include high physical and mental demands associated with poor general work conditions, frequently found in the hospital environment ${ }^{23}$.

It should be emphasized that the prevalence of inadequate work ability in women 
was $84 \%$ higher than in men. Among Italian workers, including nursing professionals, Costa and Sartori ${ }^{24}$ observed that the highest percentages of workers with a low or average WAI were females.

Several causes could be attributed to women's higher risks of showing inadequate work ability. Among these is the multiple roles taken by the majority of women who perform a professional activity. Work overload with double or triple shifts could cause women to feel physical and emotional stress, as their inclusion in the job market did not end their connection with domestic and child care tasks ${ }^{22,25}$.

With regard to work-related factors, several aspects may contribute to deteriorate work ability, such as: static muscular work, excessive muscular strength use, load lifting and transportation, repetitive movements, inadequate postures, risks of suffering work-related accidents, thermal discomfort, conflicting roles, and the lack of opportunities of development and recognition in the workplace ${ }^{7}$. In this sense, the present study identified the following variables related to work conditions, which are associated with inadequate work ability: having other jobs, insufficient number of professionals in the hospital to perform the prescribed tasks, and repetitive and monotonous tasks.

The history of nursing professionals reveals problems associated with this profession that appeared in the beginning of its implementation, both in Brazil and in other countries, which are still present to this day. Some of these problems are associated with the following: stress in nursing work, the reduced number of team professionals, the lack of professional recognition, and low salaries that cause professionals to have more than one job ${ }^{26,27}$.

With regard to the workload, having other jobs is directly associated with the increase in the number of hours worked. In the present study, the mean weekly workload was 63 hours. Johnson and Lip$\mathrm{scomb}^{28}$ identified an association between high workloads and acute stress reactions, increased cigarette use and cardiovascular and musculoskeletal diseases. Thus, it could be supposed that the increase in workload as a result of having other jobs could directly interfere with professionals' work ability, because the excessive number of working hours contributes to the development or aggravation of morbidities.

The increase in the number of diseases could also lead to a significant decrease in work ability, as suggested by Costa and Sartori ${ }^{24}$. Findings of the present study corroborate these authors', because it was possible to observe that the occurrence of inadequate work ability among individuals who reported three or more diseases was $48 \%$ higher than that of workers who did not report any diseases.

In addition, high perception of fatigue showed a statistically significant association with inadequate work ability, because the prevalence of inadequate work ability was 2.37 times higher among individuals who had high levels of fatigue, when compared to those with low levels of fatigue.

Fatigue is a physical and psychological phenomenon that reduces workers' ability to perform tasks as it changes their state of alert and vigilance, in addition to causing a decrease in motivation ${ }^{29}$, which may affect work ability.

In addition to the high prevalence of inadequate work ability, a significant number of professionals had high levels of fatigue $(25.7 \%)$. It should be emphasized that fatigue has been identified as a factor that contributes to accidents and diseases in several work sectors, including hospitals, especially when long and irregular working hours are performed. Certain effects of fatigue, such as the increase in reaction time, lack of attention in the workplace, and adoption of inadequate strategies to perform work activities have been identified as causes of work-related accidents ${ }^{30}$.

Workers who reported performing activities that were always repetitive and monotonous showed a higher prevalence of high perception of fatigue. In the study conducted by Souza et al. ${ }^{31}$, monotony and repetition were also associated with the 
prevalence of fatigue among bank workers.

Higher prevalence of fatigue was also observed among workers who reported between three and five morbidities and six or more morbidities. Peres ${ }^{32}$ states that chronic fatigue is a symptom present in several diseases, such as fibromyalgia, depression, multiple sclerosis, sleep apnea, systemic lupus erythematosus and migraine. Thus, the significant prevalence of high levels of fatigue observed in the study population could be associated with the high number of reported morbidities and/or strain resulting from the work performed by this group of nursing professionals.

\section{Study limitations}

Cause and effect relationships could not be established because of the crosssectional design of the present study.

The absence of variables associated with the duration and quality of sleep are also limitations to this study, because the reduction in sleep caused by night shifts and multiple jobs is probably associated with high perception of fatigue.

Another possible limitation to this study is associated with something known as "healthy worker's effect". Some studies in the area of occupational epidemiology point to the occurrence of better morbidity and mortality indicators among workers, when compared to the general population $^{33}$. This event can be attributed to the selection process to hire workers or to the fact that other workers were on sick leaves due to morbidities and did not participate in the study.

\section{Conclusions}

A relevant part of the population studied had an inadequate work ability. Factors such as sex, having other jobs, performing repetitive and monotonous tasks, understaffing, and reporting several morbidities were associated with inadequate work ability. These results corroborate the concept that work ability is a dynamic process, resulting from the interaction between individual factors and work-related factors.

With regard to perception of fatigue, a significant number of workers in this study reported high levels of fatigue, including factors associated with repetitive and monotonous tasks and reported clinically diagnosed morbidities.

Thus, when the characteristics of nursing work and hospital work conditions are considered, individual and group interventions of an environmental and organizational nature are required. These actions are aimed at restoring and maintaining work ability, reducing fatigue and enabling improvements in the health conditions and quality of life of this population.

Authors declared there were no conflicts of interest.

\section{References}

1. Lunardi VL, Lunardi Filho WD, Silveira RS da, Silva MRS da, Dei Svaldi JS, Bulhosa MS. A ética na enfermagem e sua relação com o poder e a organização do trabalho. Rev Lat Am Enfermagem 2007; 15: 493-7.

2. Barboza DB, Soler ZASG. Afastamento do trabalho na enfermagem: ocorrências com trabalhadores de um hospital de ensino. Rev Lat Am Enfermagem 2003; 11: 177-83.
3. Avendaño C, Bustos P, García F, Pierart T. Burnout y apoyo social en personal del servicio de psiquiatría de un hospital público. Cienc Enferm 2009; 2: 55-68.

4. Batista AAV, Vieira MJ, Cardoso NCS, Carvalho GRP de. Fatores de motivação e insatisfação no trabalho do enfermeiro. Rev Esc Enferm USP 2005; 39: 85-91.

5. Demerouti E, Le Blanc PM, Bakker AB, Schaufeli WB, Hox J. Present but sick: a three-wave study on job demands, presenteeism and burnout. Car Develop Internat 2009; 14: 50-68. 
6. Ortiz JA, Arias F. El desgaste profesional (burnout) y calidad de vida laboral como predictores de la búsqueda de otro trabajo en profesionales de la salud y de la educación en el occidente de México. Ciencia y Trabajo 2009; 11: 222-6.

7. Ilmarinen J, Tuomi K, Eskelinen L, Nygard C-H, Huuhtanen P, Klockars M. Summary and recommendations of a project involving cross-sectional and follow-up studies on the aging workers in Finnish Municipal Occupations (1981-1985). Scand JWork Environ Health 1991; 17(S1): 135-41.

8. Ilmarinen J, Tuomi K. Past present and future of work ability. In: Ilmarinen J, Lehtinen S. Past present and Future of Work Ability. Helsinki: Finnish Institute of Occupational Health 2004; 1-25.

9. Rosa PLFS, Fischer FM, Borges FNS, Soares NS, Rotenberg L, Landsbergis P. Percepção da duração do sono e da fadiga entre trabalhadores de enfermagem. $R$ Enferm UERJ 2007; 15: 100-6.

10. Lewis G, Wessely S. The epidemiology of fatigue: more questions than answers. J Epidemiol Community Health 1992; 46: 92-7.

11. Queiroz MFF. Compreendendo o conceito de fadiga [tese de doutorado]. São Paulo: Faculdade de Saúde Pública da USP; 2003.

12. Tuomi K, Ilmarinen J, Jahkola A, Katajarinne L, Tulkki A. Índice de capacidade para o trabalho. Tradução: Fischer FM (coord). São Carlos: Edufscar; 2005.

13. Martinez MC, Latorre MRDO, Fischer FM. Validade e confiabilidade da versão brasileira do Índice de Capacidade para o Trabalho. Rev Saúde Pública 2009; 43: 523-32.

14. Kujala V, Remes J, Ek E, Tammelin T, Laitinen J. Classification of work ability index among young employees. Occup Med (Lond) 2005; 55: 399-401.

15. Yoshitake H. Relations between the symptoms and the feeling of fatigue. In: Hashimoto K. et al. Methodology in human fatigue assessment. London: Taylor \& Francis; 1975.

16. Metzner RJ, Fischer FM. Fadiga e capacidade para o trabalho em turnos fixos de doze horas. Rev Saúde Pública 2001; 35: 548-53.
17. Barros AJD, Hirakata VN. Alternatives for logistic regression in cross sectional studies: an empirical comparison of models that directly estimate the prevalence ratio. BMC Med Res Methodol 2003. Disponível em: http://www.biomedcentral.com/1472288/3/21. [Acessado em 10 de março de 2010]

18. Victora CG, Huttly SR, Fuchs SC, Olinto MTA. The role of conceptual frameworks in epidemiological analysis: a hierarchical approach. Int J Epidemiol 1997; 26: 224-7.

19. Fowler Jr DJ. Survey research methods. California: SAGE; 1990.

20. Hasselhorn H-M, Tackenberg P, Camerino D, Conway PM. Work ability among nurses in Europe. In: Hasselhorn H-M, Müller BH, Tackenberg P, editors. NEXT Scientific Report: July 2005. Disponível em: http://www.next.uniwuppertal.de/EN/download. php?f=33131f960ff1150 b2 e0192c51d18f53\&target $=0$. [Acessado em 25 de novembro de 2009]

21. Fischer FM, Borges FNS, Rotenberg L, Latorre MRDO, Soares NS, Rosa PLFS, et al. Work ability of health care shift workers: what matters? Chronobiol Int 2006; 23: 1165-79.

22. Rotenberg L, Griep RH, Fischer FM, Fonseca MJM, Landsbergis P. Working at night and work ability among nursing personnel: when precarious employment makes the difference. Int Arch Occup Environ Health 2009; 82: 877-85.

23. Tepas DI, Barnes-Farrell JL, Bobko N, Fischer FM, Iskra-Golec I, Kaliterna L. The impact of night work on subjective reports of well being: an exploratory study of health care workers from five nations. Rev Saúde Pública 2004; 38(S): 26-31.

24. Costa G, Sartori S. Ageing, working hours and work ability. Ergonomics 2007; 50: 1914-30.

25. Spíndola T. Mulher, mãe ... e trabalhadora de enfermagem. Rev Esc Enferm USP 2000; 34: 354-61.

26. Carmelo SHH, Angerami ELS. Sintomas de estresse nos trabalhadores atuantes em cinco núcleos de saúde da família. Rev Lat Am Enfermagem 2004; 12: 14-21.

27. Murofuse NT, Marziale MHP. Doenças do sistema osteomuscular em trabalhadores de enfermagem. Rev Lat Am Enfermagem 2005; 13: 364-73.

28. Johnson JV, Lipscomb J. Long work hours, occupational health and the changing nature of work organization. Am J Ind Med 2006; 49: 921-9. 
29. Yamazaki S. Lifestyle and work predictors of fatigue in japanese manufacturing workers. Occup Med (Lond) 2007; 57: 262-9.

30. Mitler MM, Carskadon MA, Czeisler CA, Dement WC, Dinges DF, Graeber RC. Catastrophes, sleep, and public policy: Consensus report. Sleep 1988; 11: 100-9.

31. Souza MFM, Messing K, Meneses PR, Cho HJ. Chronic fatigue among bank workers in Brazil. Occup Med (Lond). 2002; 52: 187-94.
32. Peres MFP. Fibromialgia, fadiga e cefaléias. Einstein 2004; 2(S1): 49-57.

33. Santana VS, Cordeiro R. Detecção dos agravos à saúde relacionados como o trabalho, em estudos epidemiológicos. In: Mendes R. Patologia do trabalho. $2^{\text {a }}$ Ed., São Paulo: Atheneu; 2003. p. 199-230.

Received: 06/04/2010

Final version: 01/08/2011

Approved: 05/09/2011 